curvature. The contents consisted of a few ounces of sago mixed with small clots of blood, the whole partially digested. When the organ was floated in water, it was seen that in

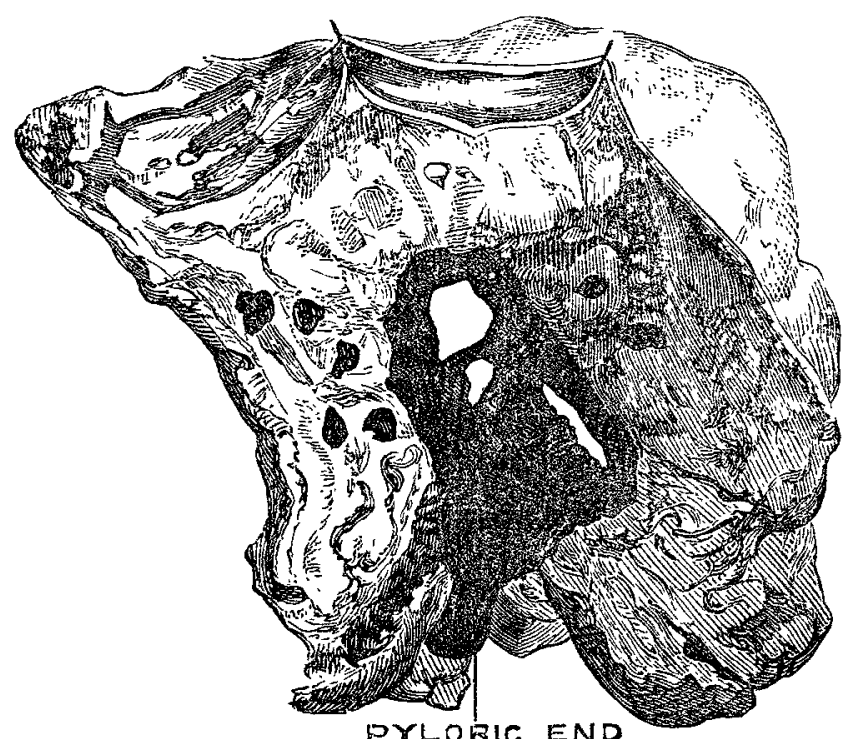

the neighbourhood of the lesser curvature, reaching quite up to the pylorus, and, as represented in the drawing, some distance down each wall, a large extravasation of blood had occurred between the mucous and muscular coats. Over the whole of this area, and at a few spots where much smaller extravasations had occurred, the mucous coat had entirely disappeared. Where the process of self-digestion had advanced furthest, the muscular coat was gone, and in these places the whole thickness of the wall had been dissolved. Through one of these openings the contents of the stomach touched a small portion of the under surface of the liver; at that spot the same process had begun, and had extended to the depth of a quarter of an inch. No further morbid appearance was observed in the stomach. The intestines were examined from end to end. There was no trace of ulceration or congestion. The contents were small in quantity, and consisted chiefly in altered blood. The colon was nearly empty. The rectum contained ordinary fæces, but no blood.

Although long a matter of dispute, it may now be considered settled that self-digestion of the stomach is a postmortem change. The case under consideration certainly supports that view, for the slightest muscular contraction either of the viscus or of the abdominal walls would certainly have caused at least partial escape of the contents.

In recording this instance, it is quite unnecessary for me to go into the general question of spontaneous solution of the stomach. Within the last few years several exhaustive papers have appeared, but so far as I have been able to examine the literature of the subject, I have not found a case similar to this-one in which the process attacked the tissues after the vitality of the mucous membrane had been reduced by extensive hæmorrhage on its under surface.

\section{THE VAPORIFER.}

BY W. L. SHEPARD, M.R.C.S., \&C., FORMERLY TUTOR AT ST. BARTHOLOMEW'S HOSPITAL.

AN apparatus which can be used either as a bronchitis kettle, an inhaler, or a portable vapour-bath ; that cannot get out of order, or burn even if allowed to boil dry ; that can be refilled without moving from the fire, or stopping the emission of steam, is, I think, likely to be useful to the profession, especially at this season. Such an apparatus, which I propose ealling the "Vaporifer," has been made for me by Messrs. Arnold and Sons, of West Smithfield. The woodcut explains sufficiently its very simple construction. It has no bottom, and when in use stands in any ordinary saucepan, so that, should it boil dry, the worst that can happen will be the spoiling of a sixpenny saucepan, easily replaced. The top of the apparatus is closed, and on its inner surface, enclosing the orifice of the steampipe, is a movable circular chamber, having a perforated bottom, on which any drugs can be placed when it is wished to medicate the vapour. The crescent-shaped front permits of the saucepan in which it stands being refilled without moving

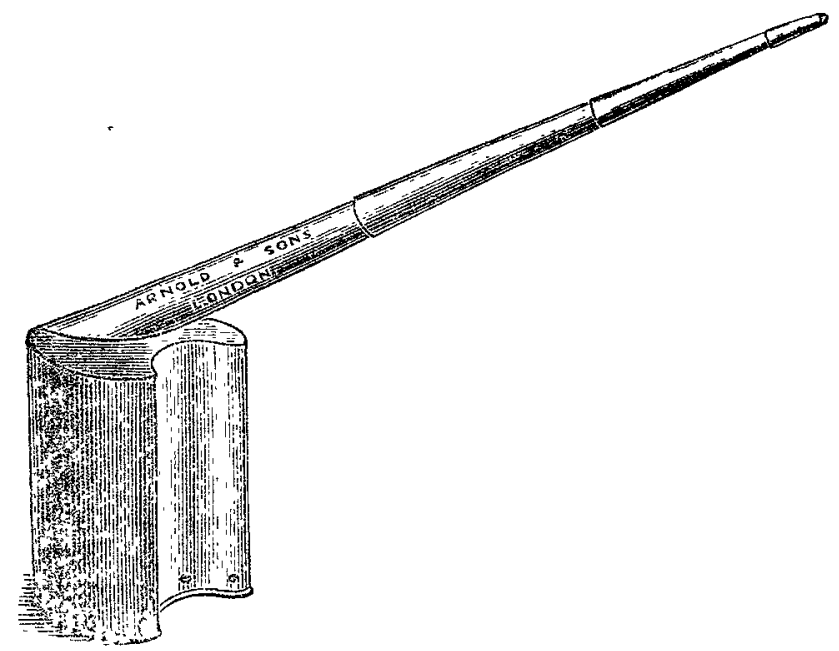

from the fire, and if boiling water be used the steam is generated continuously. By removing part of the steampipe, and affixing the mouthpiece, a very handy and efficient inhaler is formed. Placed over a gas-stove or spirit-lamp, it can be used as a portable vapour-bath. A not unimportant ad. vantage is its trifling cost, as Messrs. Arnold inform me it can be sold for less than either of the three apparatus it replaces. Lastly, it packs in a neat compact case, and may be had of the nearest chemist's, to the great saving of the family teakettle, which, hurriedly pressed into the service, displays a great deal of useless zeal by vigorously blowing its steam up the chimney, and generally comes to an untimely end by having its bottom burnt out.

Euston-road.

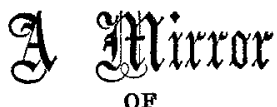

\section{HOSPITAL PRACTICE, BRITISH AND FOREIGN.}

Nulla antem est alia pro certo noscendi via, nisi quamplurimas et morborum et dissectionum historias, tum aliorum, tum proprias collectas habere, et inter se comparare.-MorgaGNI De Sed. et Caus. Morb., lib. iv. Proœmium.

\section{MIDDLESEX HOSPITAL.}

\section{A SERIES OF CASES OF FRACTURE OF THE SKULL.}

(Under the care of Mr. HuLKE.)

WE commence this week a series of interesting cases of fracture of the skull, under the care of Mr. Hulke. Every case will be found to present points of extreme interest. Some show recovery after presumed fracture of the base, and others illustrate the presence of high temperature where necroscopy failed to discover any coarse signs of inflammation, but only bruising of the bone-tissue in all.

CASE 1. Fracture of the side wall of skull; much bruising of under-surface of brain; very high temperature.-A laundress, aged fifty-five, a large heavy woman, was admitted into Bird ward at 12.45 P.M., on Dec. 18th, 1870, in a halfconscious state-not noticing what was passing around her, and not speaking unless spoken to, when she replied incoherently. Her pupils were contracted and rigid, and the right eyelids were ecchymosed. Mucous râles were audible in the chest. Pulse 76 ; temperature in armpit $98 \cdot 6^{\circ} \mathrm{F}$; respiration 32 per minute. She was said to have fallen down an area the evening before. At 5 P.M. the pulse had risen in frequency to 92, and it was very weak and intermittent. At 6.15 P.M. the pulse had become still more frequent, the temperature had greatly risen $\left(104.4^{\circ}\right)$, and the respiration was 50. The head, after being shaved, was covered with a large ice-bag; and a calomel purge was given. At 9.15 the temperature was lower $\left(102.8^{\circ}\right)$; pulse 128 ; respiration 44. As she had not passed water, and the bladder was full, the catheter was used.

Dec. 19th. - In the early morning she was slightly more conscious, and appeared to recognise her friends. The 